\title{
Preventive Health-Seeking Behaviour relating to Hypertension among Non-Teaching Staff of College of Medicine, University of Ibadan, Oyo State, Nigeria
}

\author{
Article by Mercy Uchechi Ikechukwu-Orji \\ Texila American University, Guyana, South America \\ E-mail: mercy4good@gmail.com
}

\begin{abstract}
Hypertension contributes largely to morbidity and mortality experienced from cardiovascular diseases worldwide. Studies have been conducted on hypertension among various populations in Nigeria, but only a few have provided data on hypertension-related preventive Health-Seeking Behaviour (HSB) among workers in the hospital environment. This study was conducted to determine the preventive HSB relating to hypertension among non-teaching staff of the College of Medicine, University of Ibadan (CoMUI).

A total of 315 non-teaching staff University College Hospital was involved in the study. Data were collected using a pre-tested a semi-structured questionnaire. Respondents' preventive HSB were assessed through preventive practices. Respondents' attitudes towards preventive behaviour were measured on 20-point scale. Using SPSS, Data were analysed via descriptive statistics, Chi-square and logistic regression.

Preventive behaviour by respondents included non-consumption of alcohol (65.1\%), regular BP check-up (46.3\%), regular exercise (41.9\%) and low salt intake $47.3 \%$. Few respondents (39.3\%) had positive attitude towards preventive HSB. Non-alcohol consumption was 4 times more likely to be observed (OR: 4.2; 95\% CI 2.6-6.9) while exercise was twice less likely (OR: 2.1; 95\% CI 0.3-0.7) by the respondents. Respondents' educational qualifications and administrative rank were significantly associated with preventive HSB ( $p<0.05)$. Less than half $(43.8 \%)$ of the respondents had low knowledge of hypertension prevention (screening/early detection; 14.9\%).

Although more than half of the respondents do not consume alcohol, other aspects of preventive behaviours practices were relatively low which therefore calls for effective work-place health promotion and education programme for behavioural change towards prevention of hypertension.
\end{abstract}

Keywords: Hypertension, Hypertension prevention, Hypertension risk factors, Preventive Healthseeking behaviour, University Non-teaching staff, Hospital environment.

\section{Introduction}

Globally, hypertension is recognised to be the leading course of 7.6 million untimely deaths which is about $13.5 \%$ of the world total. Being an independent risk factor for cardiovascular and cerebrovascular diseases, approximately $54 \%$ of stroke and $47 \%$ of ischemic heart disease worldwide are caused by high blood pressure (Lawes, Hoorn, and Rodgers, 2008). In 2008, World Health Organization reported of about $40 \%$ of adult aged 25years and above to have hypertension (World Health Organization, 2013). In a study conducted by Danaei et, al. on the secular trends in the ageadjusted mean systolic blood pressure (SBP) worldwide, it was discovered that population growth and aging worldwide has led to an increase in population with uncontrolled hypertension between 1980 and 2008 (Danaei, Finucane, and Lin, 2011).

In Nigeria, the case is not different as hypertension prevalence may possibly form a large proportion of the total prevalence in Africa due to the increase in population of the country which is currently predicted to be over 170 million (Adeloye, Basquill, Aderemi, Thompson, and Obi, 2015). This trend of increase in hypertension may continue with continuous increase in adult population as well as increase in changing lifestyle of Nigerians (Kayima, Wanyenze, Katamba, Leontsini, and Nuwaha, 2013). 
Health-seeking behaviour practice is recognised as an essential tool to prevent the menace of hypertension. The association among health and human behaviour is a major area of interest in public health. Kasl and Cobb 1966 identified three types of health behaviour: preventive health behaviour, illness behaviour, and sick-role behaviour. Preventive health behaviour is any activity undertaken by an individual who believes himself to be healthy in order to prevent or detect illness in an asymptomatic state (Kasl and Cobb 1966). Researches in relation to health seeking behaviour have shown its numerous influences on the health behaviour of individuals. These influences include previous experiences on health service provision, influences at the community level, perception on efficiency and quality of health service provision (Sule, Ijadunola, Onayade, Fatusi, Soetan and Connell, 2008). Furthermore, the decision to seek help is subject to the level of education of individual as well as economic status and the level of concern about the symptom and its duration (Amaghionyeodiwe, 2008).

Moreover, apart from knowledge and awareness, health seeking behaviour is affected by many other factors. These behaviour among different populations, results from factors operating at community, family and individual levels including their previous experiences with the health service provision, their bio-social profile, availability of alternative health care providers, effects at the community level as well as their perceptions about efficiency and quality of the services provided (Lurie , Hintzn and Lowe, 1995). In developed countries such as the United States, disability and premature death mainly results from chronic diseases such as hypertension, heart disease, stroke, cancer, injury, emphysema, chronic obstructive pulmonary disease, and arthritis. Several of these diseases have remained characterized as such resulting from "accumulated, multiple indiscretions" (Westberg and Jason, 1996) and linked to habitual, and sometimes harmful, ways of living. It follows that with individual's practice of certain preventive health behaviours, considerable morbidity and prematurely caused mortality could be reduced. Preventive actions in relation to hypertension can reduce; though not totally eliminate the chances of acquiring the disease. The strength of the cause and effect relationship between certain behaviour and hypertension as health problem one is trying to prevent, will determine the impact performing the behaviour will have on reducing the risk. Diet, physical activities, healthy life style and nutrition are important factors for promoting and maintaining good health throughout the entire life course (World Health Organization, 2002). Knowledge of risk factors associated with hypertension and practicing of preventive behaviours including regular blood pressure screening is critical for prompt detection and treatment of hypertension thus reducing the risk of cardiovascular disease and death.

It is assumed that there is every tendency that where one lives or works or spends the greater percentage of his/her time every day, has a way of influencing the behaviour of the person either positively or negatively. Non-Teaching Staffs of College of Medicine are non-medical professionals working in the administrative department of the college. They are believed to have the tendency and capability of making informed decisions concerning their health as a result of influence of both academic and hospital environment. How true is this assumption in terms of preventive health seeking behaviour in relation to hypertension? Although, they work in the environment saturated with health information, there is a propensity for them to have limited or inadequate information on key health issues, including hypertension

Furthermore, most of the non-teaching staff are middle income earners that have tendency to pay little or no attention to issues of health which may be due to internal and external factors, such as family pressure, family crisis, work pressure and political and economic instabilities. This study has the potential to document information on the health seeking behaviour of non-teaching staff working in the hospital environment. It also has the budding to provide wealth of information on the knowledge and attitudes of Non-Teaching Staffs of College of Medicine and factors that influence their preventive health seeking behaviour in relation to hypertension. 


\section{Objectives of the study}

1. To examine the preventive health-seeking behaviour of non-teaching staff towards hypertension prevention

2. To identify factors influencing health seeking behaviour of non-teaching staff of College of Medicine

3. To determine knowledge of hypertension and its risk factors among non-teaching staff of College of Medicine

\section{Methodology}

\section{Study area}

This study was conducted in the College of Medicine, University College Hospital (UCH), University of Ibadan, Oyo State, Nigeria. The institution is located in Ibadan North Local Government Area. The University was established on 17 November, 1948. The University was originally instituted as an independent external college of the University of London (then it was called the University College, Ibadan). College of Medicine has 44 departments with a total number of 476 Non-Teaching Staff. Thirty-six out of the forty-four departments are located at the University College Hospital, 7 at University of Ibadan, main campus and one at Ibarapa community. This study focused only on NonTeaching Staff of College of Medicine who were in the departments located in the University Teaching Hospital Ibadan (36 departments).

\section{Study population}

The study population consists of non-teaching Staff of various Departments in the College of Medicine Ibadan, who were in the University College Hospital premises.

Sampling method: purposive sampling method was used.

Sample size: The study included the total population of non-teaching Staff of the College of Medicine, University College Hospital which was 315 and as the entire population was enrolled for the study, sample size calculation was not required.

Study tools: Semi-structured questionnaire which was pretested among similar study population was used.

Collection of data: The validated semi-structured questionnaires were self-administered with the help of two female research assistants who were trained public health personnel.

Data analysis: Administered questionnaire were collected and kept away from unauthorized persons. The information collected using semi-structured questionnaire was coded, entered and analysed using Statistical Package for Social Sciences (SPSS) software, version 16.0. Both the descriptive and inferential statistics were used to analyse the quantitative data. The Regression analysis and Chi-square test was used to compare categorical variables at $0.05 \%$ level of significance.

Knowledge analysis: Respondents' knowledge of hypertension and its risk factors was analysed using knowledge scale. Ten knowledge questions were asked and points were allotted to each of the knowledge questions ( 2 points). Responses that were very close to the most correct answer were allotted 1 point. Incorrect responses were given no point. The total knowledge score and the maximum obtainable score for each respondent were calculated. The knowledge scores were graded into good, fair or poor knowledge as presented below;

Maximum knowledge score $=20$;

Poor knowledge $($ code 1$)=0-7$

Fair knowledge $($ code 2$)=8-12$

Good knowledge $($ code 3$)=13-20$ 
DOI: $10.21522 /$ TIJPH.2013.05.04.Art030

ISSN: $2520-3134$

Table 2.1. Knowledge scale on hypertension

\begin{tabular}{|c|c|c|c|}
\hline No & Question & Response/Options & $\begin{array}{l}\text { Scor } \\
\text { e }\end{array}$ \\
\hline 1 & $\begin{array}{l}\text { Hypertension is a ---- } \\
\text { - }\end{array}$ & $\begin{array}{l}\text { 1. Chronic condition that mainly affects } \\
\text { the heart, brain and kidney ( } 1 \text { pts.) } \\
\text { 2. Disease that comes with old age only } \\
\text { (1 pts.) } \\
\text { 3. An increase /elevation in the blood } \\
\text { pressure above normal ( } 2 \text { pts.) } \\
\text { 4. Normal disease that could affect } \\
\text { anybody ( } 0 \text { pt.) }\end{array}$ & \\
\hline 2 & $\begin{array}{l}\text { Which of the } \\
\text { following is the } \\
\text { normal range of } \\
\text { blood pressure? }\end{array}$ & $\begin{array}{l}1.130 / 85 \mathrm{mmHg}(2 \text { pts. }) \\
2.140 / 90 \mathrm{mmHg}(0 \text { pt. }) \\
3.160 / 100 \mathrm{mmHg}(0 \text { pt. }) \\
4.180 / 110 \mathrm{mmHg}(0 \text { pt. })\end{array}$ & \\
\hline 3 & $\begin{array}{l}\text { Which of the } \\
\text { following organs in } \\
\text { the body are } \\
\text { affected/damaged by } \\
\text { hypertension }\end{array}$ & $\begin{array}{l}\text { 1. Heart; }(0 \mathrm{pt} .) \\
\text { 2. Ear; }(2 \mathrm{pts} .) \\
\text { 3. Kidney; }(0 \mathrm{pt} .) \\
\text { 4. Brain }(0 \mathrm{pt} .)\end{array}$ & \\
\hline 4 & $\begin{array}{l}\text { Which of the } \\
\text { following is a } \\
\text { symptom of } \\
\text { hypertension }\end{array}$ & $\begin{array}{l}\text { 1. Head arch; }(0 \text { pt. }) \\
\text { 2. Malaria and typhoid ( } 0 \text { pts. }) \\
\text { 3. Diarrhoea; }(0 \text { pt. }) \\
\text { 4. None of the above }(2 \text { pts. })\end{array}$ & \\
\hline 5 & $\begin{array}{l}\text { The best way to } \\
\text { prevent hypertension } \\
\text { is }\end{array}$ & $\begin{array}{l}\text { 1. Screening/early detection (1 pt.) } \\
\text { 2. Cessation from drinking too much } \\
\text { alcohol and cigarette smoking ( } 1 \mathrm{pt} \text {.) } \\
\text { 3. Regular exercise and healthy diet (1 } \\
\text { pt.) } \\
\text { 4. All of the above ( } 2 \text { pts.) }\end{array}$ & \\
\hline 6 & $\begin{array}{l}\text { Who does } \\
\text { hypertension affect? }\end{array}$ & $\begin{array}{l}\text { 1. Men of all age ( } 1 \text { pt.) } \\
\text { 2. Women of all age }(1 \mathrm{pt} .) \\
\text { 3. Men and women of all age who } \\
\text { indulge in an unhealthy life style ( } 1 \text { pt.) } \\
\text { 4. All of the above }(2 \text { pts.) }\end{array}$ & \\
\hline 7 & $\begin{array}{l}\text { Hypertension can } \\
\text { lead to the following } \\
\text { diseases except }\end{array}$ & $\begin{array}{l}\text { 1. Heart attack }(0 \mathrm{pt} .) \\
\text { 2. Stroke and blindness }(0 \mathrm{pt} .) \\
\text { 3. Renal diseases }(0 \mathrm{pt} .) \\
\text { 4. Diarrhoea }(2 \text { pts. })\end{array}$ & \\
\hline 8 & $\begin{array}{l}\text { The following are the } \\
\text { risk factors of } \\
\text { hypertension except }\end{array}$ & $\begin{array}{l}\text { 1. Cigarette smoking and too much } \\
\text { alcohol consumption }(0 \mathrm{pt} .) \\
\text { 2. Too much salt in the diet }(0 \mathrm{pt} .) \\
\text { 3. Physical inactivity }(0 \mathrm{pt} .) \\
4 \text { talking too much }(2 \mathrm{pts} .)\end{array}$ & \\
\hline 9 & $\begin{array}{l}\text { Which of the } \\
\text { following statement } \\
\text { is true about } \\
\text { hypertension? }\end{array}$ & $\begin{array}{l}\text { 1. Unhealthy diet including consumption } \\
\text { of fast foods and high salt intake can } \\
\text { never cause hypertension ( } 0 \text { pt.) } \\
\text { 2. One can decide not to exercise at all } \\
\text { and yet will not develop hypertension ( } 0 \\
\text { pt.) } \\
\text { 3. Healthy behaviour including routine } \\
\text { screening for blood pressure and healthy }\end{array}$ & \\
\hline
\end{tabular}




\begin{tabular}{|l|l|l|l|}
\hline & & $\begin{array}{l}\text { life style and diet can prevent } \\
\text { hypertension (2 pts.) } \\
\text { 4. You are liable to having hypertension } \\
\text { at a certain age in your life no matter } \\
\text { what you do (0 pt.) }\end{array}$ & $\begin{array}{l}\text { 1. The higher the blood pressure, the } \\
\text { higher the risk of stroke, renal failure } \\
\text { and heart attack (0 pt.) } \\
\text { 2. Hypertension is a silent disease (0 pt.) } \\
\text { 3. Complication of hypertension is not } \\
\text { always severe (2 pts.) } \\
\text { 4. Hypertension can run in a family (0 } \\
\text { pt.) }\end{array}$ \\
\hline $\begin{array}{l}\text { Which of the } \\
\text { following statement } \\
\text { is not true about }\end{array}$ & \\
\hline
\end{tabular}

Analysis of Attitude to hypertension prevention: Like in the knowledge scale, respondents' preventive behaviours towards the risk factors of hypertension were measured using attitudinal scale. Ten questions were asked on preventive behaviours and points were awarded to each of the questions ( 2 points). The respondents' level of agreement or disagreement to each of the question was awarded points. This was also based on its closeness to the most right answer, while the most correct answer to the question was awarded full points ( 2 points). This was different from knowledge scale in that the points awarded to the level of disagreement and agreement to each question varies. The total attitude score and the maximum obtainable score for each respondent were calculated which was used to grade each respondents as having positive, fair or negative attitude towards hypertension risk factors.

Maximum attitude score $=20$

Negative attitude (code 1$)=0-5$

Fair attitude $($ code 2$)=6-10$

Positive attitude $($ code 3$)=11-20$

Table 2.2. Attitudinal scale for the measurement of preventive behaviour to hypertension

\begin{tabular}{|c|c|c|}
\hline $\mathbf{S} / \mathbf{N}$ & Statement & Scores \\
\hline 1 & $\begin{array}{l}\text { I consume alcohol because is good for the body no matter the quantity } \\
\text { Agree- } 0 \text { pt. Strongly agree- } 0 \text { pt. Disagree- } 1 \text { pt. Strongly disagree- } 2 \\
\text { pts. }\end{array}$ & \\
\hline 2 & $\begin{array}{l}\text { I do not smoke Cigarette because it can cause hypertension. } \\
\text { Agree- } 1 \text { pt. Strongly agree-2 pts. Disagree-0 pt. Strongly disagree-0 } \\
\text { pt. }\end{array}$ & \\
\hline 3 & $\begin{array}{l}\text { I consume fast foods regularly and I don't think I can develop } \\
\text { hypertension through that. Agree- } 0 \text { pt. Strongly agree- } 0 \text { pt. Disagree- } \\
1 \text { pt. Strongly disagree- } 2 \text { pts. }\end{array}$ & \\
\hline 4 & $\begin{array}{l}\text { I exercise regularly to prevents the chances of developing } \\
\text { hypertension } \\
\text { Agree- } 1 \text { pt. Strongly agree- } 2 \text { pts. Disagree- } 0 \text { pt. Strongly disagree-0 } \\
\text { pt. }\end{array}$ & \\
\hline 5 & $\begin{array}{l}\text { I check my blood pressure regularly for early detection of } \\
\text { hypertension } \\
\text { Agree- } 1 \text { pt. Strongly agree- } 2 \text { pts. Disagree- } 0 \text { pt. Strongly disagree - } 0 \\
\text { pt. }\end{array}$ & \\
\hline 6 & $\begin{array}{l}\text { I take too much cholesterol- containing food no matter how hard I try } \\
\text { to stop it. } \\
\text { Agree- } 0 \text { pt. Strongly agree- } 0 \text { pt. Disagree- } 1 \text { pt. Strongly disagree-2 } \\
\text { pts. }\end{array}$ & \\
\hline
\end{tabular}


DOI: $10.21522 / \mathrm{TIJPH} .2013 .05 .04 . A r t 030$

ISSN: $2520-3134$

\begin{tabular}{|c|c|}
\hline 7 & $\begin{array}{l}\text { I Consume a lot of alcohol whenever am stressed or depressed and it } \\
\text { does not affect me. } \\
\text { Agree- } 0 \text { pt. Strongly agree- } 0 \text { pt. Disagree- } 1 \text { pt. Strongly disagree-2 } \\
\text { pts. }\end{array}$ \\
\hline 8 & $\begin{array}{l}\text { I put salt in my food while eating at all time and I don't think it has } \\
\text { anything to do with hypertension } \\
\text { Agree- } 0 \text { pt. Strongly agree- } 0 \text { pt. Disagree- } 1 \text { pt. Strongly disagree- } 2 \\
\text { pts. }\end{array}$ \\
\hline 9 & $\begin{array}{l}\text { I smoke cigarette and I can't develop hypertension through that } \\
\text { Agree- } 0 \text { pt. Strongly agree-0 pt. Disagree- } 1 \text { pt. Strongly disagree- } 2 \\
\text { pts. }\end{array}$ \\
\hline 10 & $\begin{array}{l}\text { I never eat fast foods because I may likely develop hypertension if I } \\
\text { do. Agree- } 1 \text { pt. Strongly agree- } 2 \text { pts. Disagree- } 0 \text { pt. Strongly } \\
\text { disagree- } 0 \text { pt. }\end{array}$ \\
\hline
\end{tabular}

\section{Results}

\section{Socio-demographic characteristics of the respondents}

The age group of the respondents were mainly between 31years and 50years as represented on table 3.1. Furthermore, figures 3.13 .2 , and 3.3 shows the sex, educational qualifications and marital status of the respondents which pointed out that more female (58.4\%) than male (41.6\%)participated in the survey.

Table 3.1. Age group of respondents (mean age: $42.8 \pm 13.2$ years)

\begin{tabular}{|l|l|l|}
\hline \multicolumn{1}{|c|}{ Variable } & Number & \multicolumn{1}{c|}{ Percentage (\%) } \\
\hline Age group (years) & & \\
\hline $21-30$ & 57 & 18.1 \\
\hline $31-40$ & 107 & 34.0 \\
\hline $41-50$ & 96 & 30.5 \\
\hline $51-60$ & 55 & 17.5 \\
\hline Total & $\mathbf{3 1 5}$ & $\mathbf{1 0 0 . 0}$ \\
\hline
\end{tabular}

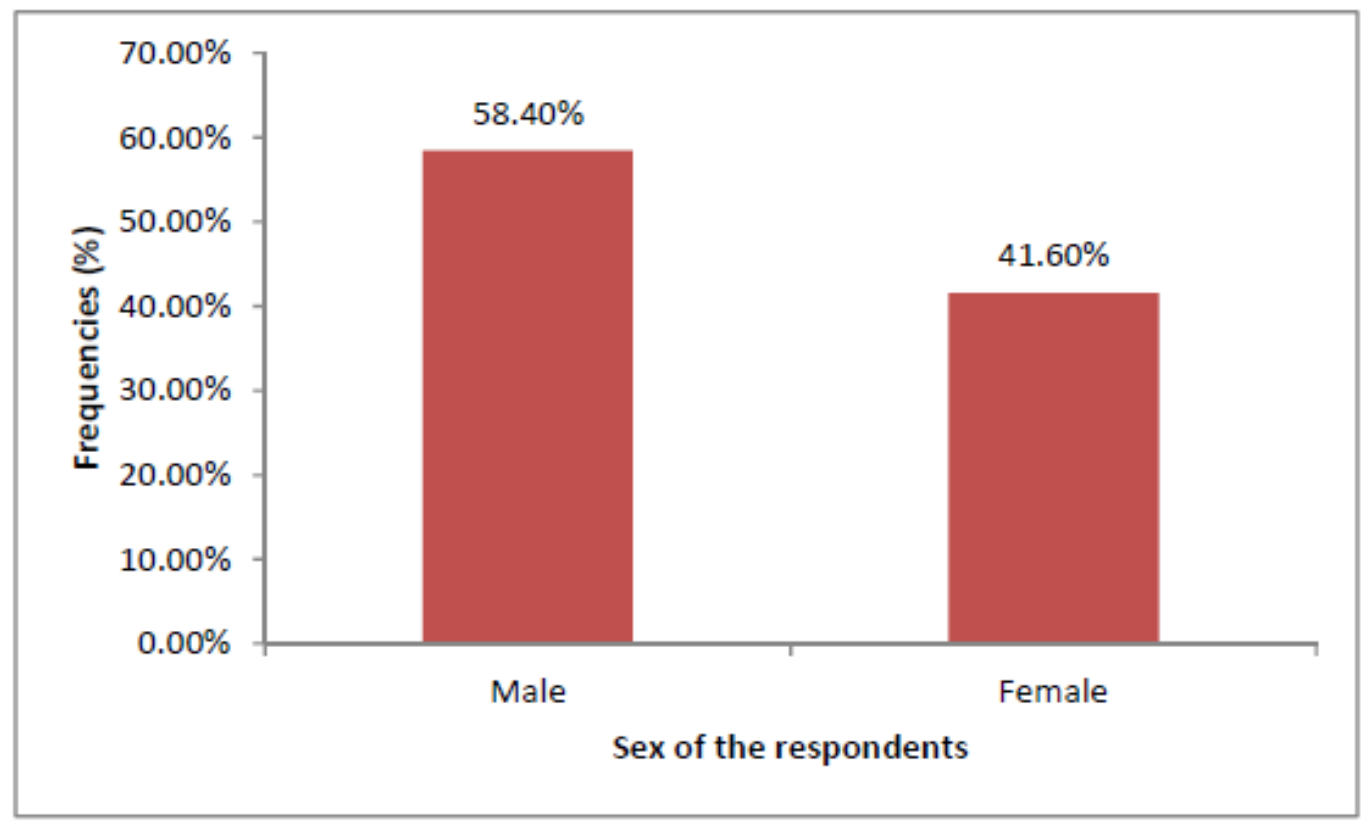

Figure 3.1. Sex distribution of the respondents 


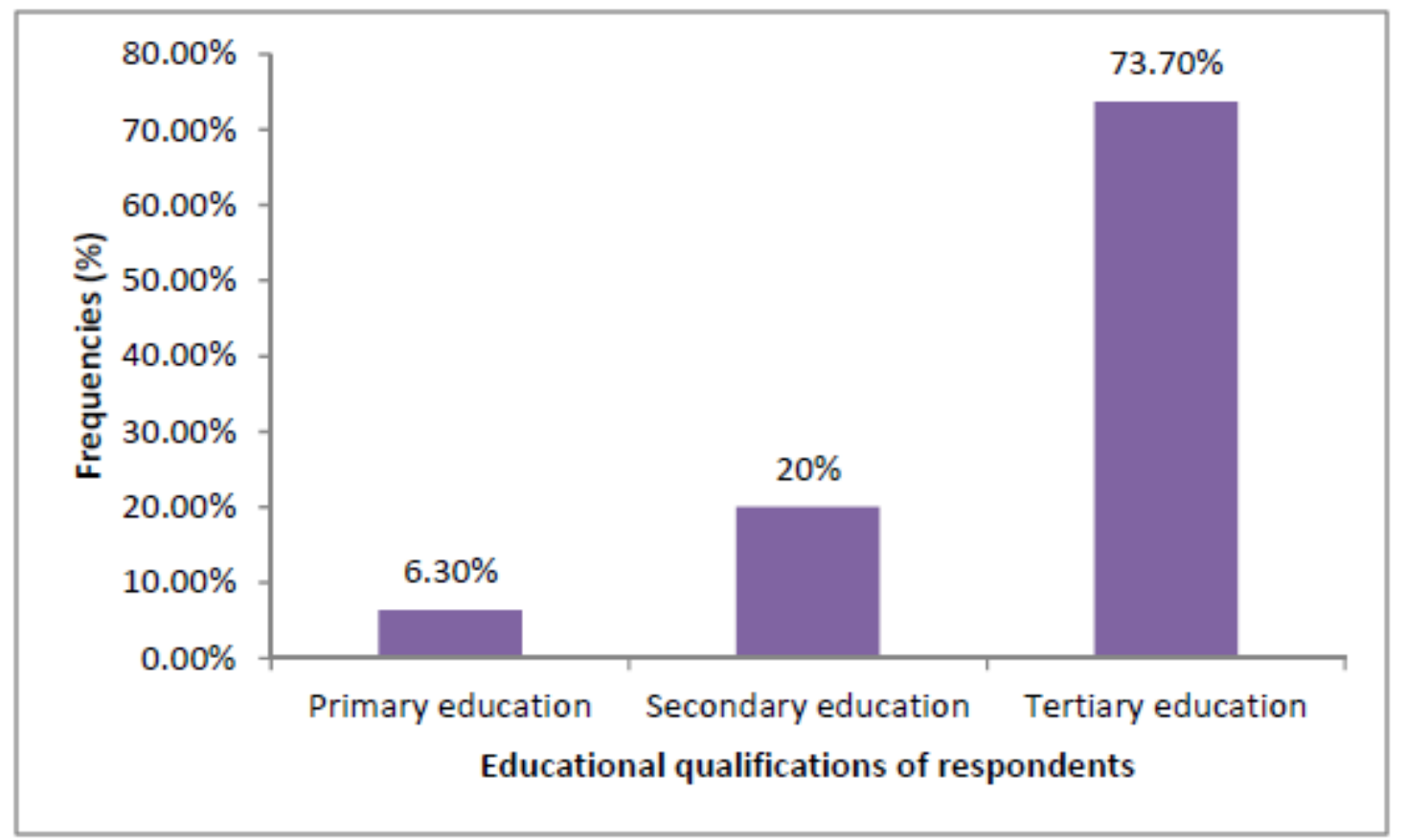

Figure 3.2. Distribution of educational qualification of the respondents

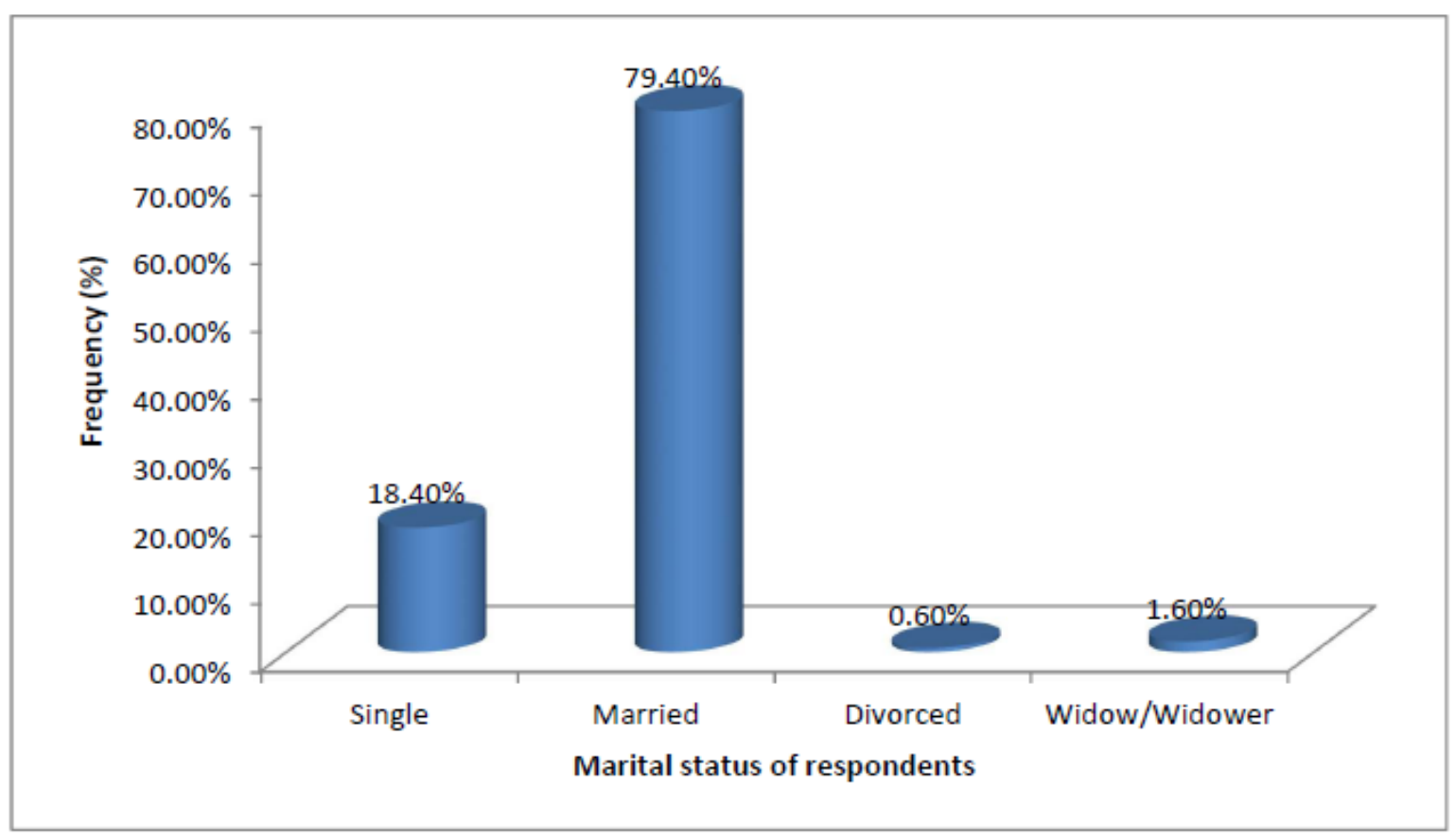

Figure 3.3. Marital status of the respondents

\section{Knowledge of hypertension and its risk factors}

Findings from the survey show that $57.5 \%$ respondents accepted the fact that hypertension is an increase/elevation in the blood pressure above normal while $51.7 \%$ acknowledged that healthy behaviour including routine screening for blood pressure and healthy life style and diet can prevent hypertension. Greater percentage (73.3\%) of the respondents identified talking too much as one of the risk factors of hypertension. Two hundred and nineteen (69.5\%) were of the opinion that headache is a symptom of hypertension while $14.3 \%$ stated that hypertension has no symptom; thus a silent disease. (See table 3.2 for details). 
DOI: $10.21522 / \mathrm{TIJPH} .2013 .05 .04 . A r t 030$

ISSN: $2520-3134$

Table 3.2a. Respondents' knowledge of hypertension and its risk factors

\begin{tabular}{|c|c|c|}
\hline Knowledge items & $\begin{array}{l}\text { Frequenc } \\
y\end{array}$ & Percentage (\%) \\
\hline $\begin{array}{l}\text { Definition of Hypertension } \\
\text { Chronic condition that mainly affects the } \\
\text { heart, brain and kidney } \\
\text { Disease that comes with old age only } \\
\text { An increase /elevation in the blood pressure } \\
\text { above normal } \\
\text { Normal disease that could affect anybody } \\
\text { Don't know }\end{array}$ & $\begin{array}{l}54 \\
24 \\
181 \\
39 \\
17\end{array}$ & $\begin{array}{l}17.1 \\
7.6 \\
57.5 \\
12.4 \\
5.4\end{array}$ \\
\hline $\begin{array}{l}\text { Normal range of blood pressure } \\
120 / 80 \mathrm{mmHg} \\
140 / 90 \mathrm{mmHg} \\
160 / 100 \mathrm{mmHg} \\
180 / 110 \mathrm{mmHg} \\
\text { Don't know }\end{array}$ & $\begin{array}{l}227 \\
40 \\
10 \\
2 \\
36\end{array}$ & $\begin{array}{l}72.1 \\
12.7 \\
3.2 \\
0.6 \\
11.4\end{array}$ \\
\hline $\begin{array}{l}\text { Organs in the body not affected/damaged } \\
\text { by hypertension } \\
\text { Heart } \\
\text { Ear } \\
\text { Kidney } \\
\text { Brain } \\
\text { Don't know }\end{array}$ & $\begin{array}{l}16 \\
232 \\
28 \\
18 \\
21\end{array}$ & $\begin{array}{l}5.1 \\
73.7 \\
8.9 \\
5.7 \\
6.7\end{array}$ \\
\hline $\begin{array}{l}\text { Symptom of hypertension } \\
\text { Head ache } \\
\text { Malaria and typhoid } \\
\text { Diarrhoea } \\
\text { None of the above } \\
\text { Don't know }\end{array}$ & $\begin{array}{l}219 \\
11 \\
24 \\
45 \\
16\end{array}$ & $\begin{array}{l}69.5 \\
3.5 \\
7.6 \\
14.3\end{array}$ \\
\hline $\begin{array}{l}\text { The best way to prevent hypertension } \\
\text { Screening/early detection } \\
\text { Cessation from drinking too much alcohol and } \\
\text { cigarette Smoking } \\
\text { Regular exercise and healthy diet } \\
\text { All of the above } \\
\text { Don't know }\end{array}$ & $\begin{array}{l}47 \\
51 \\
66 \\
138 \\
13\end{array}$ & $\begin{array}{l}14.9 \\
16.2 \\
21.0 \\
43.8 \\
4.1\end{array}$ \\
\hline $\begin{array}{l}\text { Those at risk of hypertension } \\
\text { Men of all age } \\
\text { Women of all age }\end{array}$ & 4 & $\begin{array}{l}1.3 \\
1.9\end{array}$ \\
\hline
\end{tabular}


Texila International Journal of Public Health

Volume 5, Issue 4, Dec 2017

\begin{tabular}{|c|c|c|}
\hline $\begin{array}{l}\text { Men and women of all age who indulge in an } \\
\text { unhealthy life style } \\
\text { All of the above }\end{array}$ & 8 & 2.5 \\
\hline \multicolumn{3}{|l|}{ Disease that is not caused by hypertension } \\
\hline Heart attack & 9 & 2.9 \\
\hline Stroke and blindness & 2 & 0.6 \\
\hline Renal diseases & 26 & 8.3 \\
\hline Diarrhoea & 262 & 83.2 \\
\hline Don't knows & 16 & 5.1 \\
\hline \multicolumn{3}{|l|}{ Non- risk factor of hypertension } \\
\hline $\begin{array}{l}\text { Cigarette smoking and too much alcohol } \\
\text { consumption }\end{array}$ & 7 & 2.2 \\
\hline Too much salt in the diet & 18 & 5.7 \\
\hline Physical inactivity & 47 & 14.9 \\
\hline Talking too much & 231 & 73.3 \\
\hline Don't know & 12 & 3.8 \\
\hline \multicolumn{3}{|l|}{ True statement about hypertension } \\
\hline $\begin{array}{l}\text { Unhealthy diet including consumption of fast } \\
\text { foods and high salt intake can never cause } \\
\text { hypertension. }\end{array}$ & 51 & 16.2 \\
\hline $\begin{array}{l}\text { One can decide not to exercise at all and yet } \\
\text { will not develop hypertension. }\end{array}$ & 32 & 10.2 \\
\hline $\begin{array}{l}\text { Healthy behaviour including routine screening } \\
\text { for blood pressure and healthy life style and }\end{array}$ & 163 & 51.7 \\
\hline $\begin{array}{l}\text { You are liable to having hypertension at a } \\
\text { certain age in your life no matter what you do. } \\
\text { Don't know }\end{array}$ & 53 & $\begin{array}{l}16.8 \\
5.1\end{array}$ \\
\hline Non- true statement about hypertension & & \\
\hline $\begin{array}{l}\text { The higher the blood pressure, the higher the } \\
\text { risk of stroke, renal failure and heart attack }\end{array}$ & 22 & 7.0 \\
\hline Hypertension is a silent disease & 32 & 10.2 \\
\hline Complication of hypertension is not always & 143 & 45.4 \\
\hline Hypertension can run in a family & 96 & 30.5 \\
\hline Don't know & 22 & 7.0 \\
\hline
\end{tabular}

From table 3.2a, it is shown that more than half of the respondents had an above average knowledge score, which is good knowledge score $-62.2 \%$, Less than a third had fair knowledge score $-27.9 \%$ and approximately one tenth had poor knowledge score $-9.8 \%$. (See figure 3.4 for graphical representation.). 
DOI: 10.21522/TIJPH.2013.05.04.Art030

ISSN: $2520-3134$

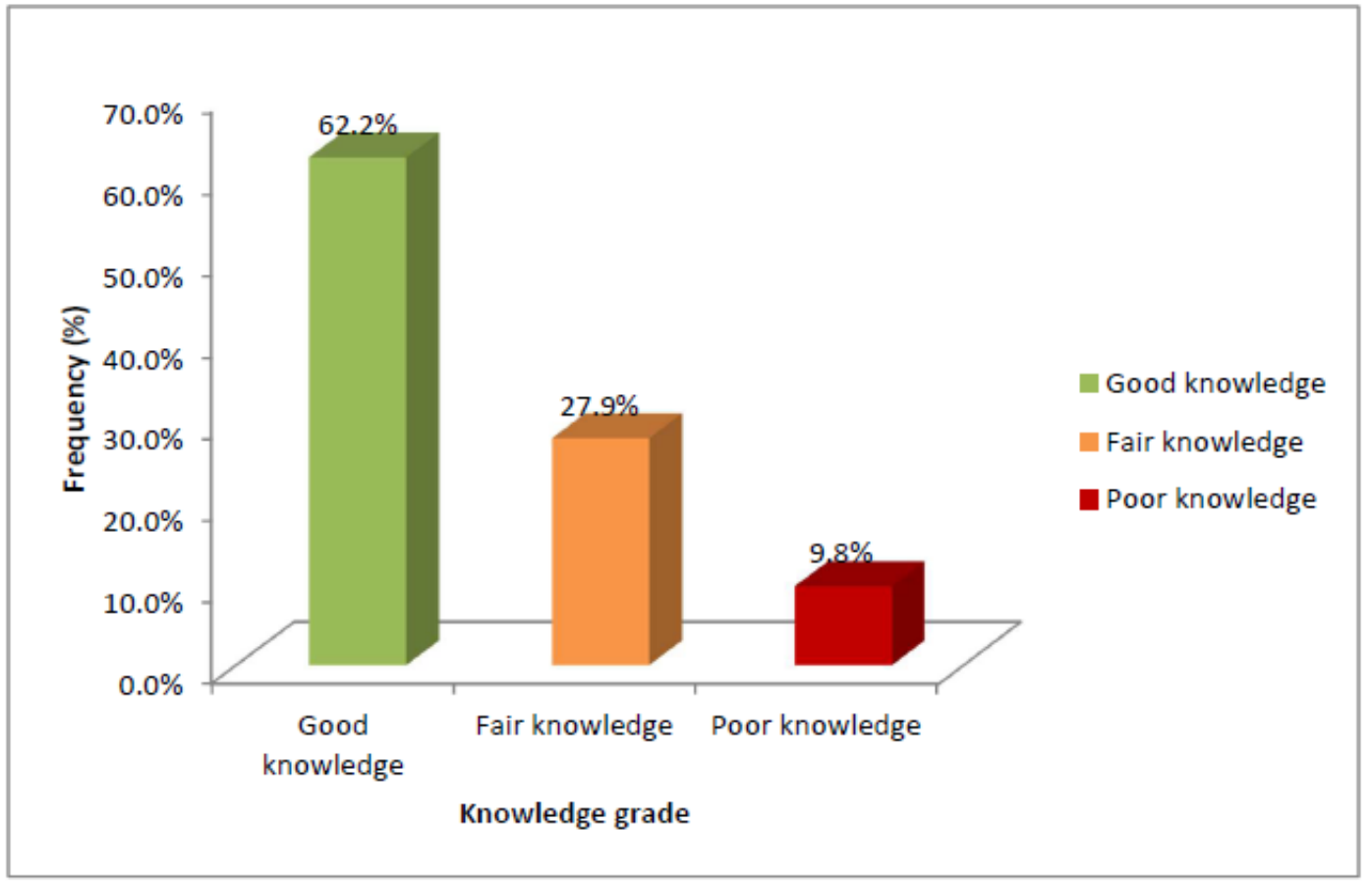

Figure 3.4. Respondents' knowledge of hypertension and its risk factors

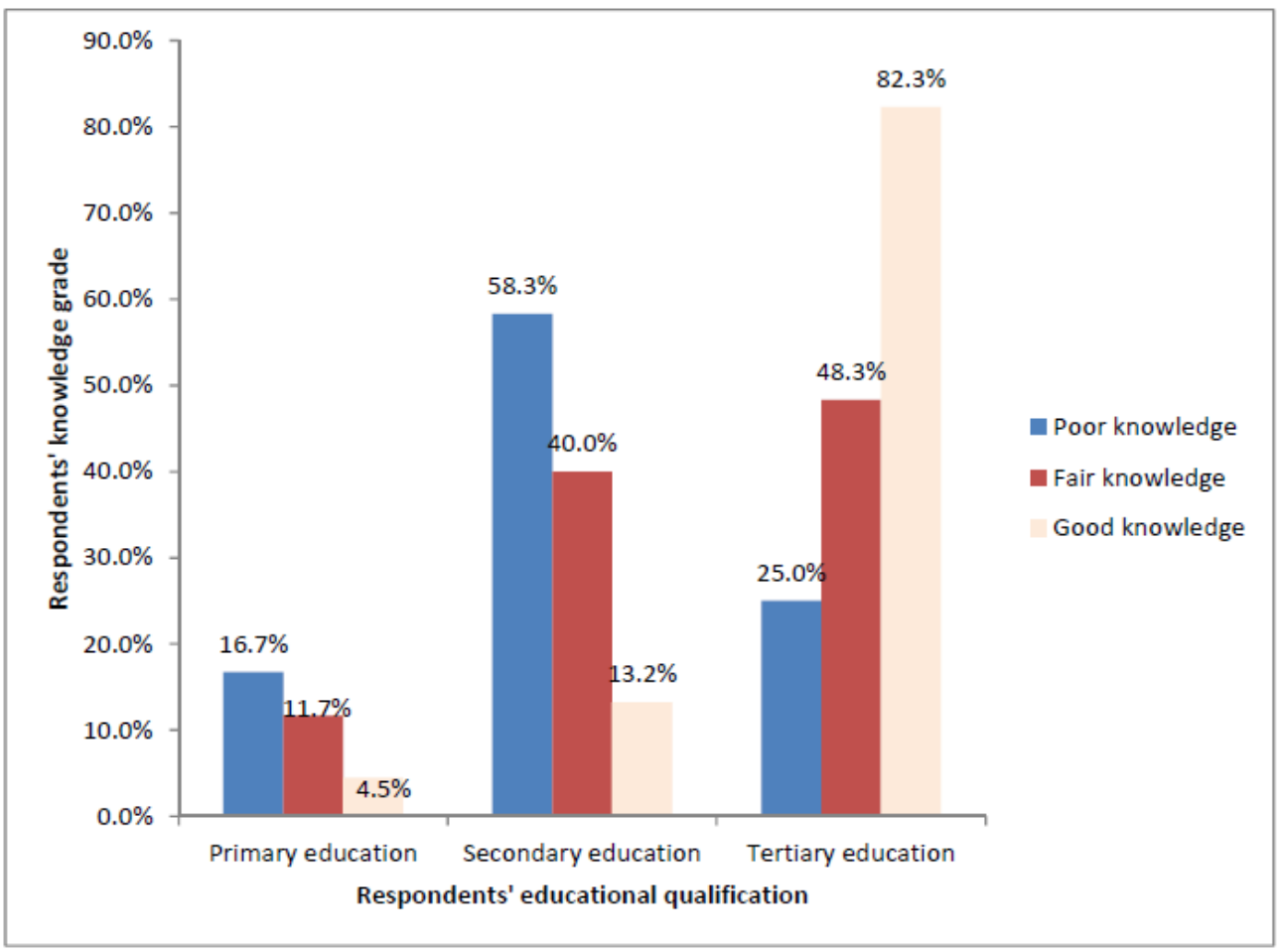

Figure 3.5. Respondents' knowledge of hypertension and educational qualification

$$
\text { P-value }=0.000, \mathrm{X}^{2}=43.9
$$

\section{Preventive behaviours towards hypertension}

Furthermore result from the survey showed that the respondents were aware of behaviours which can pre-dispose to hypertension but practice less of regular exercise and fast-food consumption as represented in Tables 3.3 
Texila International Journal of Public Health Volume 5, Issue 4, Dec 2017

Table 3.3. Respondents' preventive behaviours in relation to hypertension using attitudinal scale

\begin{tabular}{|c|c|c|c|c|c|c|}
\hline Statement & $\begin{array}{l}\text { Agree } \\
(\%)\end{array}$ & $\begin{array}{l}\text { Strongly } \\
\text { Agree (\%) }\end{array}$ & $\begin{array}{l}\text { Disagree } \\
(\%)\end{array}$ & $\begin{array}{l}\text { Strongly } \\
\text { Disagree } \\
(\%)\end{array}$ & $\begin{array}{l}\text { Total } \\
(\%)\end{array}$ & score \\
\hline $\begin{array}{l}\text { I consume alcohol because is } \\
\text { good for the body no matter } \\
\text { the quantity }\end{array}$ & $\begin{array}{l}6 \\
(1.9)\end{array}$ & $\begin{array}{l}34 \\
(10.8)\end{array}$ & $\begin{array}{l}70 \\
(22.2)\end{array}$ & $\begin{array}{l}205 \\
(65.1)\end{array}$ & $\begin{array}{l}315 \\
(100.0)\end{array}$ & \\
\hline $\begin{array}{l}\text { I do not smoke cigarette } \\
\text { because it can cause } \\
\text { hypertension. }\end{array}$ & $\begin{array}{l}119 \\
(37.8)\end{array}$ & $\begin{array}{l}126 \\
(40.0)\end{array}$ & $\begin{array}{l}40 \\
(12.7)\end{array}$ & $\begin{array}{l}30 \\
(9.5)\end{array}$ & $\begin{array}{l}315 \\
(100.0)\end{array}$ & \\
\hline $\begin{array}{l}\text { I consume fast foods } \\
\text { regularly and I don't think I } \\
\text { can develop hypertension } \\
\text { through that. }\end{array}$ & $\begin{array}{l}65 \\
(20.6)\end{array}$ & $\begin{array}{l}78 \\
(24.8)\end{array}$ & $\begin{array}{l}107 \\
(34.0)\end{array}$ & $\begin{array}{l}65 \\
(20.6)\end{array}$ & $\begin{array}{l}315 \\
(100.0)\end{array}$ & \\
\hline $\begin{array}{l}\text { I exercise regularly to } \\
\text { prevents the chances of } \\
\text { developing hypertension }\end{array}$ & $\begin{array}{l}110 \\
(34.9)\end{array}$ & $\begin{array}{l}132 \\
(41.9)\end{array}$ & $\begin{array}{l}53 \\
(16.8)\end{array}$ & $\begin{array}{l}20 \\
(6.3)\end{array}$ & $\begin{array}{l}315 \\
(100.0)\end{array}$ & \\
\hline $\begin{array}{l}\text { I check my blood pressure } \\
\text { regularly for early detection } \\
\text { of hypertension }\end{array}$ & $\begin{array}{l}134 \\
(42.5)\end{array}$ & $\begin{array}{l}146 \\
(46.3)\end{array}$ & $\begin{array}{l}20 \\
(6.3)\end{array}$ & $\begin{array}{l}15 \\
(4.8)\end{array}$ & $\begin{array}{l}315 \\
(100.0)\end{array}$ & \\
\hline $\begin{array}{l}\text { I take too much cholesterol- } \\
\text { containing food no matter } \\
\text { how hard I try to stop it. }\end{array}$ & $\begin{array}{l}33 \\
(10.5)\end{array}$ & $\begin{array}{l}89 \\
(28.3)\end{array}$ & $\begin{array}{l}90 \\
(28.6)\end{array}$ & $\begin{array}{l}103 \\
(32.7)\end{array}$ & $\begin{array}{l}315 \\
(100.0)\end{array}$ & \\
\hline $\begin{array}{l}\text { I Consume a lot of alcohol } \\
\text { whenever am stressed or } \\
\text { depressed and it does not } \\
\text { affect me. }\end{array}$ & $\begin{array}{l}11 \\
(3.5)\end{array}$ & $\begin{array}{l}26 \\
(8.3)\end{array}$ & $\begin{array}{l}64 \\
(20.3)\end{array}$ & $\begin{array}{l}214 \\
(67.9)\end{array}$ & $\begin{array}{l}315 \\
(100.0)\end{array}$ & \\
\hline $\begin{array}{l}\text { I put salt in my food while } \\
\text { eating at all time and I don't } \\
\text { think it has anything to do } \\
\text { with hypertension }\end{array}$ & $\begin{array}{l}44 \\
(14.0)\end{array}$ & $\begin{array}{l}50 \\
(15.9)\end{array}$ & $\begin{array}{l}72 \\
(22.9)\end{array}$ & $\begin{array}{l}149 \\
(47.3)\end{array}$ & $\begin{array}{l}315 \\
(100.0)\end{array}$ & \\
\hline $\begin{array}{l}\text { I smoke cigarette and I can't } \\
\text { develop hypertension } \\
\text { through that }\end{array}$ & $\begin{array}{l}30 \\
(9.5)\end{array}$ & $\begin{array}{l}38 \\
(12.1)\end{array}$ & $\begin{array}{l}88 \\
(27.9)\end{array}$ & $\begin{array}{l}159 \\
(50.5)\end{array}$ & $\begin{array}{l}315 \\
(100.0)\end{array}$ & \\
\hline $\begin{array}{l}\text { I never eat fast foods } \\
\text { because I may likely develop } \\
\text { hypertension if I do. }\end{array}$ & $\begin{array}{l}70 \\
(22.2)\end{array}$ & $\begin{array}{l}48 \\
(15.2)\end{array}$ & $\begin{array}{l}79 \\
(25.1)\end{array}$ & $\begin{array}{l}118 \\
(37.5)\end{array}$ & $\begin{array}{l}315 \\
(100.0)\end{array}$ & \\
\hline
\end{tabular}

A good number $(65.1 \%)$ of the respondents showed preventive behaviour towards alcohol consumption by strongly disagreeing to consume alcohol no matter the quantity. Also, only $41.95 \%$ of the respondents strongly agreed that they exercise regularly to prevent the chances of developing hypertension and $46.3 \%$ check their blood pressure regularly for early detection of hypertension.

However, owning to the fact that preventive health-seeking behaviour refers to their attitude in this study, attitudinal scale was used to measure the respondents' behaviour towards the prevention of hypertension. Figure 3.6 shows the attitudinal grade of the respondents' towards the preventive behaviour. 
DOI: $10.21522 /$ TIJPH.2013.05.04.Art030

ISSN: $2520-3134$

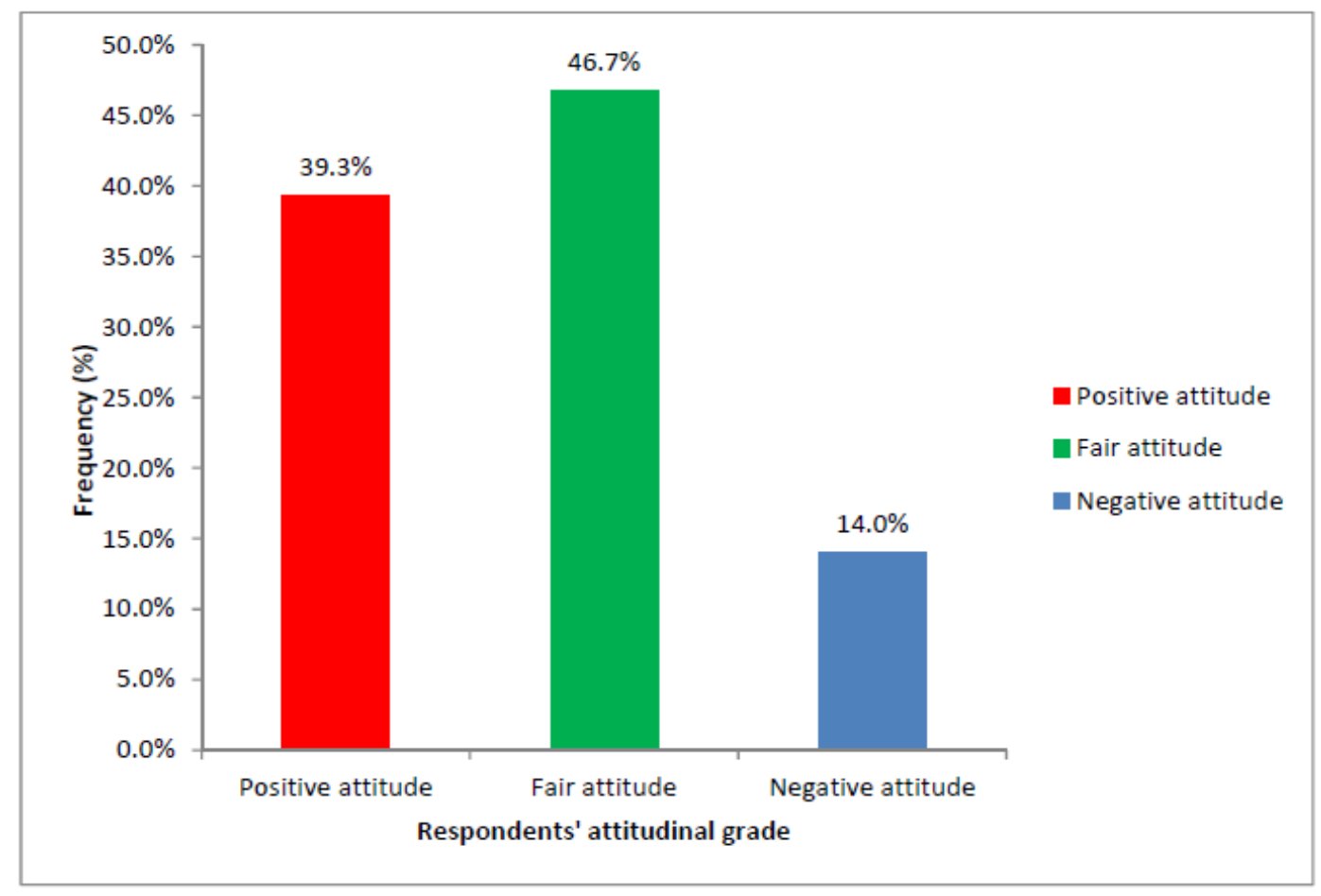

Figure 3.6. Respondents' attitudinal grade towards hypertension prevention

The attitudinal grade by age group shows that 20.2\% of age group 21-30 years had positive attitude, $33.1 \%$ for age group $31-40$ years, $32.3 \%$ for age group $41-50$ years and $32.7 \%$ for age group 51-60 years. More so, 50.8\% and $49.2 \%$ of male and female respectively had positive attitude to preventive behaviour while $75.0 \%$ and $25.0 \%$ of male and female respectively had negative attitude (Figure 3.6).

The percentage of respondents with primary education who had positive attitude to preventive behaviour was $0.0 \%$, secondary education was $7.3 \%$ while tertiary $92.7 \%$ indicating that the higher the educational qualification of the respondents, the more positive their attitude towards preventive behaviour. The attitudinal grade by years of service indicated that greater percentage $(59.2 \%)$ of those who have been in service for more than 10 years had positive attitude while $40.8 \%$ of the respondents that worked for less than 10 years in the college had positive attitude 


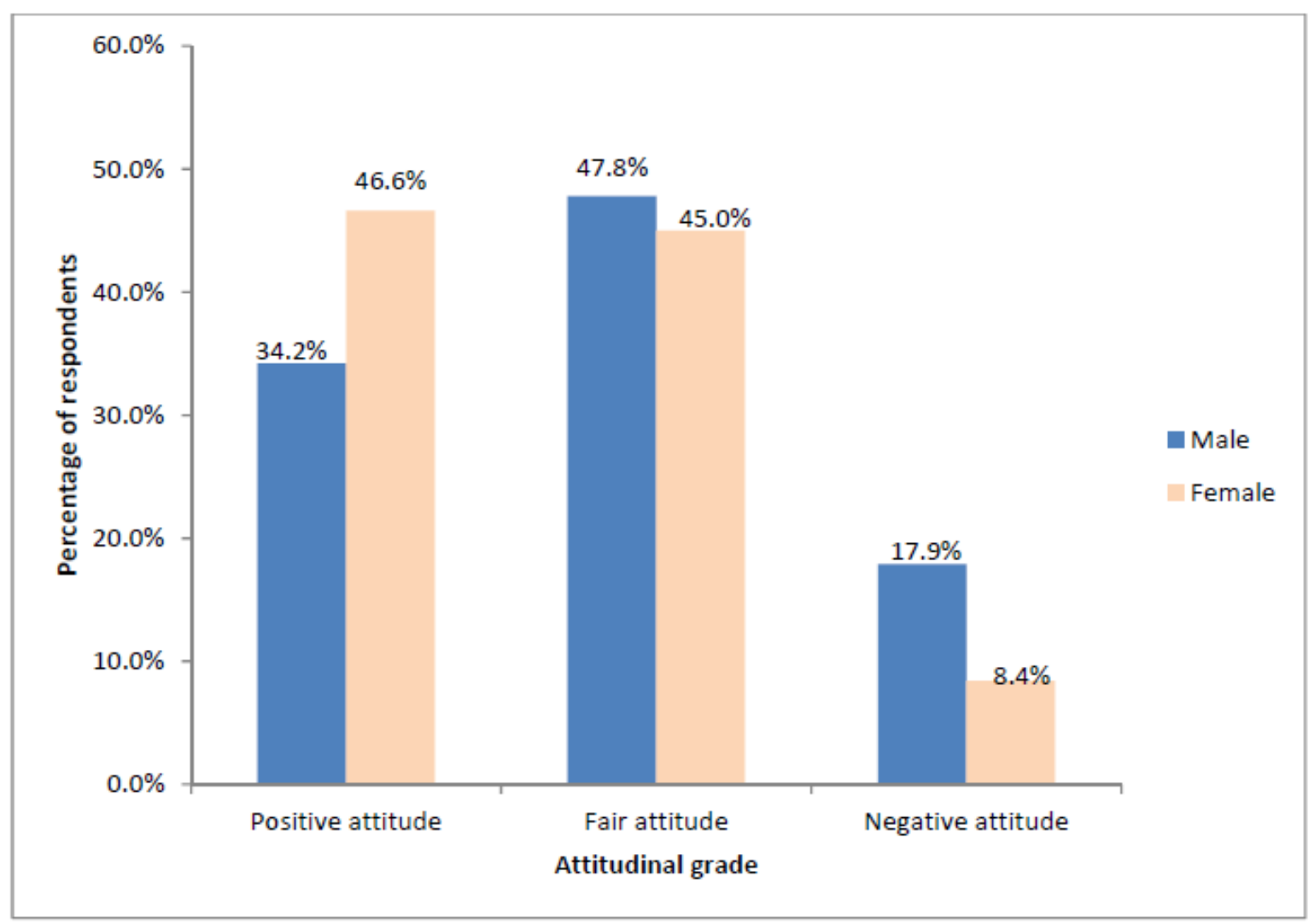

Figure 3.7. Attitudinal grades of respondents by sex

\section{P-value $=0.018$}

$\mathrm{X}^{2}=8.064$

\section{Factors influencing preventive health seeking behaviour}

In expressing their views on some factors believed to influence their preventive behaviour both negatively and positively, one hundred and eight respondents $(60.3 \%)$ reported that ill health is one of the factors that could influence staff to check their blood pressure regularly while some others (45.4\%) reported that old age and desire to know one's health status could be another factor. A few of the respondents $(8.6 \%)$ considered time as another factor which could influence regular checking of blood pressure by staff. Table 3.4 shows respondents response on this issue.

Table 3.4. Responses of the respondents on the factors that can influence staff to check their blood pressure regularly $(\mathrm{N}=315)$

\begin{tabular}{|l|l|l|}
\hline Responses & Frequency & $\begin{array}{l}\text { Percentage of } \\
\text { cases (\%) }\end{array}$ \\
\hline Ill health & 190 & 60.3 \\
\hline Desire to know one's health status /age & 143 & 45.4 \\
\hline $\begin{array}{l}\text { Health information /enlightenment } \\
\text { programme }\end{array}$ & 65 & 20.6 \\
\hline Being a hypertensive patient & 103 & 32.7 \\
\hline Stress & 113 & 35.9 \\
\hline Mobile services & 49 & 15.6 \\
\hline Personal commitment & 46 & 14.6 \\
\hline Being part of rules and regulations & 33 & 10.5 \\
\hline Time & 27 & 8.6 \\
\hline
\end{tabular}

* Multiple responses 
Abstaining from food that could predispose to hypertension, $64.8 \%$ of the respondents acknowledged that providing health information or health education to complement self-discipline remains one of the strongest factors while $60.3 \%$ recognised being concern for one's health as another factor. Few $(21.3 \%)$ of the respondents stated that abstaining from food that could predispose to hypertension is not easy when a staff has some financial constraints coupled with his or her belief (Table 3.5).

Table 3.5. Respondents' views on the factors that could influence staff to abstain from eating food that could predispose to hypertension $(\mathrm{N}=315)$

\begin{tabular}{|l|l|l|}
\hline Response & Frequency & $\begin{array}{l}\text { Percentage of } \\
\text { cases (\%) }\end{array}$ \\
\hline $\begin{array}{l}\text { Health information/health } \\
\text { education/self-discipline }\end{array}$ & 204 & 64.8 \\
\hline Habit of bringing food from home & 42 & 13.3 \\
\hline Enlightenment/ awareness programme & 124 & 39.4 \\
\hline Being a hypertensive patient & 65 & 20.6 \\
\hline Concern about one's health & 190 & 60.3 \\
\hline Financial constraints and belief & 67 & 21.3 \\
\hline
\end{tabular}

* Multiple responses

Responding to how staff could be motivated to checking their blood pressure regularly, 382 $(121.3 \%)$ of the respondents reported that providing health education for the staff and also health information is one of the factors while $58.1 \%$ reported free and easy access to health facilities as another factor.

\section{Discussion}

\section{Knowledge of hypertension and its risk factors}

From the study, it was found that $62.2 \%$ of the study population had good knowledge on hypertension and its risk factors. This is like the community based study done in Kinondoni, Dar es Salaam where it was seen that $66.8 \%$ had knowledge of hypertension and only $19.8 \%$ had knowledge of the risk factors of hypertension (Mlunde Linda, 2007). The result presented in the previous chapter also indicated that the knowledge of risk factors of hypertension increased with educational status of the respondent. The possible reason being that the higher the educational attainment, the more advanced in knowledge. A similar study which considered knowledge with respect to educational attainment, though not on hypertension, but on risk factors of stroke among hypertensive patients recorded low knowledge among the participants as a result of low educational attainment (John, 2006).

Many of the respondents were of the opinion that headache remains a symptom of hypertension. This correlate with the findings from a similar study conducted in Ogun State, Nigeria which found out that only one in every ten respondent knew that hypertension is a disease that for most times runs a symptomless course (Oluranti; Abayomi and Olutoyin 2004). Conversely, it contradicts the findings by Godfrey, Iyalomhe and Sarah (2010) that discovered that $60.2 \%$ of the participants did not recognise headache as a symptom of hypertension. The differences could result from the fact that the current study is hospital- based, thus working in the hospital environment may have influenced the respondents by having regular contacts with hypertensive patients who complain of headache. However most of the symptoms experienced are due to the target organ which has been damaged.

Additionally, this study found male respondents to have more knowledge than female, which is in contrast to the study conducted in Indian Ocean islands where female participants were found to have more knowledge (13\%) than male $(8 \%)$.

\section{Preventive health-seeking behaviours in relation to hypertension}

Less than half (39.3\%) of the participants had positive attitude to preventive behaviours in relation to hypertension. Majority of the respondent strongly disagreed that they do not consume alcohol 
because of the knowledge they have about its adverse effect in the body. This is also seen in the result of the logistic regression, which shows that among the behaviour practiced in order to prevent hypertension, non-alcohol consumption is more likely to be practiced by the respondents while regular exercise is less likely to be practiced. However, few others did not see anything wrong with alcohol no matter the quantity. This agrees with the previous study conducted in sub-urban Nigeria community by Godfrey and Sarah (2010) where more than half of the respondents were seen to disagree with the issue of alcohol consumption. Also, few of the respondents would exercise regularly in order to prevent the chances of developing hypertension.

It is gratifying to know that the preventive behaviours of the respondents towards hypertension were not impressive. This could be due to their ignorance of the possible health information and services in the environment where they work. Furthermore it is expected that working in an academic and hospital environment also could have had a positive effect on them but the reverse was the case. Notwithstanding, the possibility that most of the non-teaching staff might be having good relationship with the teaching staff as well as the students and thus, get enlightened especially on the issue relating to hypertension and its preventive mechanism, yet their attitude proved otherwise. The low positive attitude of the respondents depicts their poor practices in the prevention of hypertension. This is in relation to the previous study by Godfrey and Sarah (2010) where attitude and life style practices were assessed as one. This shows that the practices of preventive behaviour cannot be predicted from the knowledge of such behaviour.

\section{Factors influencing health seeking behaviour}

Health information/health education/self-discipline and concern about one's health were spontaneously mentioned as factors that could influence staff to abstain from eating food capable of exposing them to hypertension. Most of the respondents did not see anything in their working environment that could help in promoting their health. Their inability to recognise anything that could help in promoting their health in the work environment is likely to have resulted from ignorant or improper orientation at the time of employment.

Finally, some of the respondents hammered on the issue of having access to health information through seminars and health talk. It is very obvious that without health information, practising good health seeking behaviour will not be possible.

\section{Conclusion}

This study has shown that having good knowledge of a thing does not guarantee its practice. In this study, the respondents had remarkable knowledge of hypertension and its risk factors but their practice was poor. A lot of attention is focused on the prevention and control of communicable diseases while the non-communicable ones like hypertension go unchecked. In the case of hypertension prevention, this study has proven that regular exercise is not taken seriously even among workers in the health environment who should be privy to health information. It has also shown that creating awareness and having access to health information on disease prevention and control is the key factor to preventing the occurrence of such disease especially hypertension. There is need for programmes targeted at control of non-communicable diseases like hypertension, which is symptomless. Members of non-teaching staff, both senior and junior should have access to Information Education and Communication (IEC) on hypertension to facilitate regular screening to detect and initiate treatment earlier as well as promotion of a healthy lifestyle that may prevent or delay its onset and complications.

\section{Recommendations}

The following recommendations are made to address the findings of this research

- Health programmes including living a healthy life style should be regularly organized among the non-teaching staff at least once every month.

- The management should institute a work- place health policy that will reinforce health seeking behaviour of the staff in relation to hypertension, bearing in mind the fact that hypertension is a silent killer. 
DOI: $10.21522 /$ TIJPH.2013.05.04.Art030

ISSN: $2520-3134$

- Health programmes should be institutionalized with the aim of encouraging regular exercises among the staff.

- Staff should be properly oriented at the point of employment on their health benefits within the working environment

- There should be mass screening for all non-teaching staff for at least once every month for early detection and treatment.

- Establishing a health club among non-teaching will also go a long way in enlightening nonteaching staff, both senior and junior on the risk factors associated with non-communicable diseases including hypertension.

- The non-teaching staff should be provided with work-place information handbills/sticker against hypertension

\section{References}

[1]. Adeloye D, Basquill C, Aderemi AV, Thompson JY, Obi FA (2015). An estimate of the prevalence of hypertension in Nigeria: a systematic review and meta-analysis. J Hypertens 2015; 33: 230-242. doi: 10.1097/HJH.0000000000000413 [PubMed].

[2]. Amaghionyeodiwe LA (2008). Determinants of the choice of health care provider in Nigeria. Health. Health Care Management Science; 11 (3): 215-227.

[3]. Danaei G., Finucane M. M., JLin. K. et al. (2011), "National, regional, and global trends in systolic blood pressure since 1980: systematic analysis of health examination surveys and epidemiological studies with 786 country-years and 5.4 million participants. Global Burden of Metabolic Risk Factors of Chronic Diseases Collaborating Group (Blood Pressure)," The Lancet, vol. 377, no. 9765, pp. 568-577, 2011. View at Publisher . View at Google Scholar • View at Scopus.

[4]. Godfrey, B.S. Iyalomhe and Sarah I. Iyalomhe (2010). Hypertension-related knowledge, attitudes and lifestyle practices among hypertensive patients in a sub-urban Nigerian community Journal of Public Health and Epidemiology Vol. 2(4), pp.71-77.

[5]. John Joseph Tesha (2006) Knowledge of stroke among hypertensive patients in selected hospitals in the Tanga Region, Tanzania Retrieved on June 2010, available online http://www3.who.int/icf/onlinebrowser/icf.cfm.

[6]. Kasl, S. V., and Cobb, S. (1966). "Health Behavior, Illness Behavior, and Sick Role Behavior." Archives of Environmental Health 12:246-266,531-541.

[7]. Kayima J, Wanyenze RK, Katamba A, Leontsini E, Nuwaha F. (2013). Hypertension awareness, treatment and control in Africa: a systematic review. BMC Cardiovasc Disord 2013; 13:54 doi: 10.1186/1471-2261-13-54 [PMC free article] [PubMed].

[8]. Khor, GL (2001) cardiovascular epidemiology in the Asia-Pacific region. Asia Pac J Clin Nutr; 10:76-80.

[9]. Lawes C. M., Hoorn S. V., and Rodgers A., (2008) "Global burden of blood-pressure-related disease, 2001," The Lancet, vol. 371, no. 9623, pp. 1513-1518, 2008. View at Publisher · View at Google Scholar . View at Scopus.

[10]. Lurie P, Hintzn P and Lowe R A. (1995) Socioeconomic obstacles to HIV prevention and treatment in developing countries: the roles of the International Monetary Fund.

[11]. Mlunde Linda (2007) Knowledge, Attitude and Practices Towards Risk Factors for Hypertension in Kinondoni Municipality, Dar es Salaam DMSJ Vol. 14 No.2.

[12]. Oluranti B. Familoni, S. Abayomi Ogun and A. Olutoyin Aina (2004). Knowledge and Awareness of Hypertension among Patients with Systemic Hypertension. Journal of the National Medical Association Vol. 96, No. 5.

[13]. Sule SS, Ijadunola KT, Onayade AA, Fatusi AO, Soetan RO and Connell FA (2008). A study on the utilization of primary health care facilities in a rural community, Nigerian journal of medicine; vol 17 (1): 98106.

[14]. Westberg, J., and Jason, H. (1996). "Influencing Health Behavior." In Health Promotion and Disease Prevention in Clinical Practice, eds. S. H. Woolfe, S. Jonas, and R. Lawrence. Baltimore, MD: Williams and Wilkins.

[15]. World Health Organization, (2002). Reducing risks, promoting healthy life. The world health report Geneva. 
Texila International Journal of Public Health Volume 5, Issue 4, Dec 2017

[16]. World Health Organization, (2013) "Global brief on hypertension," 2013, http://apps.who.int/iris/bitstream/10665/79059/1/WHO_DCO_WHD_2013.2_eng.pdf?ua=1. 